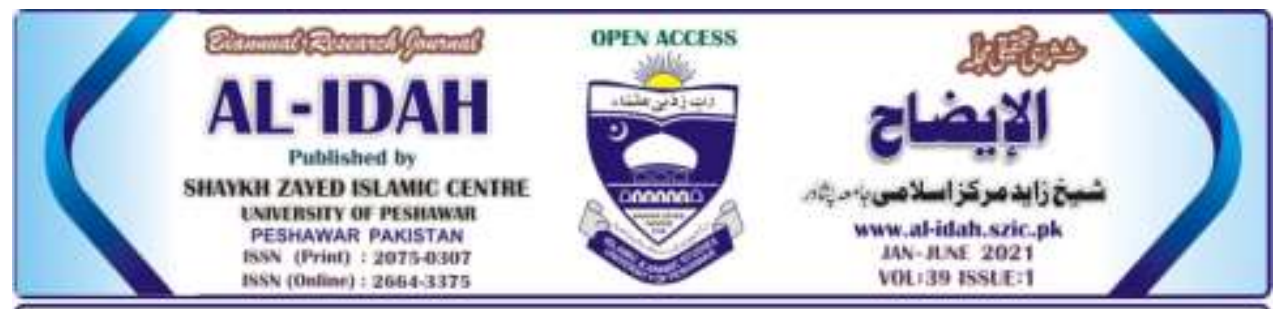

\title{
A Critical Study of G. H. A Juynboll's Methodology in the Study of Hadīth
}

\section{Author(s): Dr. Alam Khan}

Assistant Professor, Department of Hadith, Faculty of Theology, University of Gumushane -Turkey

Email: alamiiu09@gumushane.edu.tr

\section{Issue:}

http://al-idah.szic.pk/index.php/al-idah/issue/view/34

URL:

http://al-idah.szic.pk/index.php/al-

idah/article/view/724.

Citation: khan, A. 2021. A Critical Study of G. H. A Juynboll's Methodology in the Study of Hadith. AlIdah. 39, - 1 (Jun. 2021), 12 - 22.

Publisher: Shaykh Zayed Islamic Centre, University of Peshawar, Al-Idah - Vol: 39 Issue: 1 / Jan - June 2021/ P. 12 - 22.

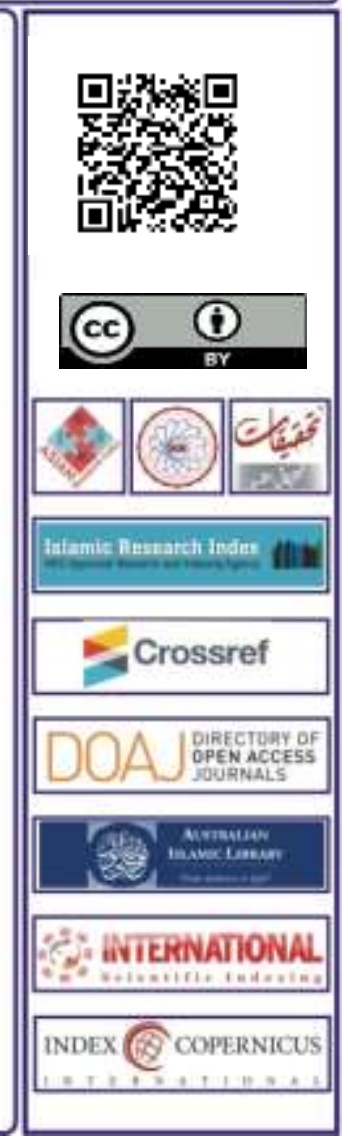

Article DOI:

https://doi.org/10.37556/al-idah.039.01.0724

Received on: $\quad 21-$ Feb - 2021

Accepted on: $\quad 11-$ April - 2021

Published on: $\quad 30$ - June 2021 


\begin{abstract}
:
This article analyzes methodology of an Orientalist, G. H. A Juynboll in Hadith. He is one of those western scholars who has focused on the second primary source of Islamic Law and has developed skeptical theories related to its authenticity and provenance. He relied on early scholars' theories in this discipline and supported their thesis with a bulk of arguments from the early Classical Islamic Sources. A follow-up of his methodology reveals some scientific methodological errors in his studies on Hadith that led him to a false conclusion. This study discusses the loopholes in his methodology and supports every point with illustrative examples from his works, revealing that Juynboll followed a selective method in his studies and reached his desired/concocted conclusion.
\end{abstract}

Keywords:

Hadīth, Orientalism, Methodology, Theories, Conclusion

\title{
Introduction:
}

Ignaz Goldziher (d. 1339/1921) was considered the first orientalist who systematically studied the second source of Islamic law. He challenged the authenticity of Prophetic hadīths and presented an ambiguous picture of prominent narrators. Besides, he claimed that Muawiyah b. 'Abī Sufyān officially ordered his governer al-Mughirah to fabricate hadiths in praise of Uthmān and his companions as well as in the defamation of $A l \bar{\imath} \quad b . A b \bar{\imath}$ Tălib and his companions. ${ }^{1}$

Goldziher is a follower of the German-British Orientalist Joseph Schacht (d. 1389/1969) in his research and questions the legislative position of Sunnah and its transmission from the Prophet. He concludes that the Sunnah has emerged by virtue of jurisprudential differences in Islamic society. Moreover, he introduced new theories in the study of Mutūn and Isnäds, such as the background of Isnād and Common-link theory. The difference between Ignaz Goldzher and Joseph Schacht is that the former focused on studying Mutūn, and the second examined the Isnād of Prophetic hadiths. ${ }^{2}$

G. H. A Juynboll (d. 1431/2010) is weighed as an authority in Orientalism and Islamic studies after two scholars mentioned above. He pursued their approaches, connected their methodologies and developed their theories. He is considered a vital source for researchers in the present era. Hence, it might be interesting for the researchers to know about his methodology in the study of Prophetic hadith.

\section{G. H. A Juynboll and Orientalism:}

Gautier Hindrik Albert Juynboll opened his eyes in a Dutch Jewish family in (1354/1935), known for his keen interest in Oriental studies. The first one who introduced Orientalism to this family was his grandfather Theodorus Willem Johannes Juynboll (d. 1277/1861). He studied semantic languages and became a professor of Hebrew and Arabic language at the University of Leiden. His son 
Abraham Willem Theodorus Juynboll (d. 1304/1887) specialized in Oriental studies like his father. He was teaching Islamic studies at Colonial Institute at Delft. However, his elder son Theodorus Willem Juynboll (d. 1367/1948) specialised in Islamic studies and the Hebrew language and appointed as a professor of Islamic studies at the University of Utrecht. His era's pious scholars and intellectuals were sensitised towards him when he edited the Holy Torah of Abū'l-Hussain al-Sāmirī. ${ }^{3}$

Likewise, his younger son Hendrik Herman Juynboll (d. 1364/1940) studied Indonesian cultures and was considered among its experts at Leiden University. Later he served as a director of the Institute of Ethnology. His daughter, Wilhelmina Maria Cornelia Juynboll (d. 1402/1982), was also one of the eminent orientalists who did her $\mathrm{PhD}$ in the history of the Arabic language in Holland. She transferred the family's scientific library to her nephew Gautier Hindrik Albert Juynboll, the last orientalist of Juynboll's family. ${ }^{4}$

There is inadequate information about G. H. A Juynboll's early life. However, in some of his biographical works, he learned Arabic and Hebrew languages in his childhood as he was ageing in a scientific and intellectual family. He was enrolled in the department of Hebrew and Arabic language at the University of Leiden in $1956 .{ }^{5}$ It was the golden period in Leiden history because prominent orientalists like Joseph Schacht (d. 1389/1969), Drewes (d. 1412/1992) and Brugman (d. 1425/2004) were delivering lectures in the Arabic language and Islamic studies at the University of Leiden at that time. Juyboll was mentored by these eminent scholars and learnt Arabic at an advanced level. Later he taught Arabic in Leiden until the mid-sixties. ${ }^{6}$

G. H. A Juynboll had to choose for career the Oriental Languages or the Indonesian Cultures, as all the Orientalists of his family specialised in one of them. However, after attending Joseph Schacht and Brugman lectures, he chose another discipline that no one of the Theodorus Willem Johannes Juynboll family had ever specialised in. He was keen to research the second source of Islamic law - Prophetic Sunnah-. Consequently, he registered his doctorate under the supervision of Brugman entitled "The Authenticity of the Tradition Literature: Discussion in Modern Egypt". He travelled to Cairo and stayed there a year to collect the primary sources for his research.

What indicates his eagerness to collect the original sources for his study is what he stated in one of his articles that he saw a book in the library of the American University in Cairo that publication was officially restricted; So he could not get it, he went to the Secretary-General of the Dutch Embassy Dr. Nicolaas Biegman and asked him to get a copy of that book and send it in the diplomatic bag to Leiden University. He used his diplomatic links and transferred that book from the library of American University in Cairo to Leiden University's library. ${ }^{7}$

He completed his doctorate - PhD- under Jan Brugman's supervision in 1969 and left for America with his family. Moreover, he was appointed on a contract basis as a lecturer of Islamic studies at the University of California Los Angeles. However, after political and administrative turmoil in America, he returned to his country. A year later, he left for UK Britain and became a professor at the 
University of Exeter. He served there for eleven years from 1974 to 1985 . During his stay in Britain, Juynboll got acquainted with researchers and orientalists from different countries and published his famous work "Muslim tradition" in 1983 and presented detailed studies on "Common-link, al-Qussās, al-Hadīth al-Mutawātir and 'Ilmu'r-Rijāl."8

He was unhappy with his work at the University of Exeter and resigned in 1985. Moreover, he moved to the native land and lived in Hague and limited himself to studying the primary sources of Islam. He visited the University of Leiden library daily while sitting in a reserve study room about Oriental studies and examined Arabic and other sources. However, he could not carry books, so the library administration provided him with a book cart to carry books and transport them to the Oriental reading hall. With the passage of time, that book cart became a sign of his presence in the library. ${ }^{9}$

It is revealed from Juynboll's biographical pieces of information that he was part of the well-known Tuhfatu'l-Ahwazi project and studied the Muslim studies of Ignaz Goldziher, which arose some questions in his mind that compelled him to find their answers. Hence, he focused on the study of hadith literature and left all official and personal activities. Throughout his research, he took part in seminars and conferences related to Orientalism. He studied 'Ahädìth and criticized the theories of Muhaddithün about the authenticity and provenance of hadith on new methods that reveal his expertise in the science of hadith.

G. H. A Juynboll died on December 9, 2010. Thus, the history of the Juynboll family interrupted. Because he was the last Orientalist in Theodorus Willem Johannes Juynboll, he left several scientific academic works that have significantly impacted researchers in the East and West. In recognition of his contribution to Orientalism, the University of Leiden announced a scholarship the Juynboll Fellowship- with the Juynboll Foundation's collaboration that the researchers from eastern and western countries avail every year. ${ }^{10}$

\subsection{A Glance on G. H. A Juynboll works:}

G. H. A Juynboll was one of those orientalists who worked on the different department of Hadith and Orientalism. A thorough review of his works reveals that he presented his theories as well as supported the thesis of his predecessors such as Ignaz Goldziher, Joseph Schacht, and James Robson (d. 1401/1981) about the history and provenance of hadith. Some of his prominent writings are as follow:

\subsubsection{The Authenticity of the Tradition Literature: Discussion in Modern Egypt:}

It was submitted by Juynboll for a doctorate under Jan Brugman's supervision at the University of Leiden in 1969. He discussed the important subjects of hadith and the theories of Muhammad' Abduh (d. 1323/1905) about the authenticity of 'Ahädìth in it. Moreover, he put a glance at the codification of Prophetic hadiths, 'Adālatu'r-Ruwāt such as 'Abü Huraìra, the transmission of the hadīth, and alIsräiliyāt. He mentioned his theories in the introduction to the thesis. However, he did not address it in the main research. Additionally, he tried to discuss the subjects in light of earlier and contemporary scholars' research. Besides, he 
concluded his thesis with the discussion of the Ahādith related to Prophetic medicine.

\subsubsection{Muslim Tradition: Studies in the Chronology, Provenance and Authorship of Early Hadīth:}

In this study, Juynboll developed the theory of Schacht about the fabrication of Prophetic hadith. He believes that it is better to attribute the 'Ahädith cluster to the later Muhaddīthün instead of Prophet Muhammad. Juynboll began his book on the article related to the origins of hadith and discussed the al- 'Awäil in hadith literature. He concluded that Islamic jurisprudence did not deduct from Prophetic hadìth. However, the later Muhaddithiun took the Fatwas of the earlier jurists and attributed it to the Prophet Muhammad. He supported his thesis on various examples from the canonical hadith compilations that a Fatwa of a jurist in the second-century A.H recorded as a Prophetic hadith in the third-century A.H. ${ }^{11}$

Additionally, he discussed al-Qudhāt and Mrākizu'l-Hadīth in Medina, Iraq, and Egypt and pointed out the fundamental differences between judges towards hadith. He concluded that Syrian and Egypt's judges did not rely upon hadìth like Medani and Iraqi judges in their judgments. Likewise, he discussed al-Mutwātir and argued that being a hadīth al-Mutwätir does not guarantee his provenance from the Prophet. Then, he presented a detailed study of some narrators from Tahdhīb al-Tahdhìb of Ibn Hajar (d. 852/1448) and concluded that the Namesakes and Common names used in the fabrication of hadith. He devoted the final chapter to the study's conclusion and the differences between Ibn Hajar and other scholars of al-Jarha wa't-Tadil. He concluded his work on the Commonlink theory's detailed study and added new terminologies like Seeming Commonlink and Partial Common-link. ${ }^{12}$

\subsubsection{Encyclopedia of Canonical Hadīth:}

It was a reward of Juynboll's endless visits to the University of Leiden library, which he continued since his return from Britain to the Netherlands in 1985 until its publishing in 2007. He collected the hadiths in order according to the narrators -Mdāru'l-Hadìth -, and listed the narrators in alphabetical order.

G. H. A Juynboll indicated the purpose of the mentioned study in its introduction that it is the translation of 'Ahädith of al-Kutub as-Sitta. Moreover, he discussed the theory of Common-link. His phrases reveal that he changed his opinion regarding Common-link because, in the beginning, he was supporting Joseph Schacht's thesis that the Common-link fabricated the transmitted hadith. However, when discussing the Common-link theory in the mentioned study, he makes him responsible for those specific words and does not call him the fabricator as Schacht. ${ }^{13}$

He translated and commented on the selected 'Ahädith as well as investigated their chains. He mentioned the biographical information of Prophet's companions, the well-known narrator from al-Tabiūn and the compilers of the canonical compilations such as Mālik, 'Abdu'r-Razzāq al-Sana' $\bar{a} n \bar{\imath}$ and others. Furthermore, Juynboll wrote valuable articles about Arabic literature and Quranic studies, ${ }^{14}$ which were published in different academic journals. Eleven of them published 
under the title "Studies on the Origins and Uses of Islamic Hadith" by Aldershot in 1996.

2. G. H. A Juynboll's Methodology in the Study of Hadīth:

G. H. A Juynboll did not adhere to one method in his studies. However, a thorough follow-up of his studies on the hadith reveals that he followed the Inferential and Historical process in general in the study and criticism of the Prophetic hadith, Which can be abridged in the following points:

1. G. H. A Juynboll concentrated on studying the Isnād system in the criticism of the 'Ahädith and presented a detailed study of the chains of those Mutūn that he wanted to criticise. He usually mentions the Matan and then lists it all chains. Sometimes he explains it on a diagram revealing the Common link and his students, which he called Partial Common link. It is noticed that he uses these terminologies in Abbreviate form. For instance, he referred to the Matan cluster with (Mc), to the Common-link with (CL) and the Seeming Common-link with (Scl). The main objective of his study of the chains is to find out the Common-link because he believes that its finding is the critical point of distinction between acceptable and fabricated Ahādith. Therefore, he studied the chains and tried to date a hadith through Common-link. ${ }^{15}$

2. He refers to the study and extraction (al-Takhrij) of a hadith into those compiled sources in the early ages of Islam and then deduces the date of their appearance based on their presence in those works as it is apparent from his study of the al-Hadīth al-Mutwätir. He researched in the early books of Hijaz, Iraq, and Egypt and concluded that the hadith (Man kazaba Aliyya ...) did not appear in Hijaz and Egypt before the year (180/796). Because we do not find it in al-Muwatta of Mālik (d. 179/795), and al-'Jāmi of Abdullāh b. Wahhab (d. 197/813). The first ones who recorded it in the Hijaz and Egypt were Imām al-Shāfi'

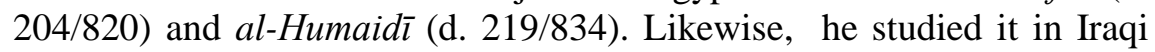
sources and claimed that the mentioned hadith did not appear in Iraq before (170/787) because we could find it only in those books, which were compiled after that. He claimed that $A b \bar{u}$ Dāwīd al-Tiālisī (d. 204) was its first source in Iraq. ${ }^{16}$

3. A thorough review of Juynboll works reveals that he relied on al-Tabaqāt $a l-K u b r a \bar{a}$ of Ibn Saad (d. 230/845) in narrators' research. However, if he did not find the biographical information of a narrator in it, he declared him suspected and doubted his existence and historical position. Furthermore, he claimed that he was fabricated and was added to the chains in the later ages. For instance, he researched the biography of Nāfi Mawlā Ibn Omar in al-Tabaqāt al-Kubrā and did not find.

Consequently, he declared him a fabricated narrator. Likewise, he suspected the existence of those narrators named "Hafs b. Omar" historically because they all were the students of Shu'ba b. al-Hajjajj (d. 160/777). However, Ibn Sa'ad only listed one of them called Hafs $b$. Omar al-Hawdhi. ${ }^{17}$ 
4. He usually mentioned his predecessors' conclusion in the preface that he was admired and then supported those findings on a vast number of arguments from Classical Islamic Sources. As for his research method in Islamic sources, he refers to historical sources first and then canonical hadìth compilations, as shown in his article on al-Hadìth al-Mutwätir and explanation of the word Fitna and its historical background in the tradition of Ibn Sirin (d. 110/729). ${ }^{18}$

5. He was meticulous about the study of the hadith. He took care of wording differences between Mutūn of hadīth and explained them as much as possible. Moreover, he listed the terms and words he wanted to explain or criticise in their original form in Latin letters and avoided their translation unless he felt the need for them.

\section{Notes on G. H. A Juynboll's Methodology:}

Juynboll has followed the evolving methodology in his studies and benefited from ancient and modern sources. He was one of those orientalists who were famous for their patience, devotion and hardworking. His well-known work, Encyclopedia of Canonical Hadith, is an example of that, which is considered the summary of his scientific research life after returning from Britain to Leiden in 1985 and published in 2007. However, there are some methodological notes on his studies which are as follow.

\subsection{Generalisation in the Conclusion:}

He researched the sources available to him but generalised his conclusions, which is not apropos in scientific research, as long as he did not examine them all. There are more than evidence of his Indulgence in generalising his conclusion. However, one example might be enough for fear of prolongation. He investigated the Isnāds and Shuyūkh of Imām' Abū Hanifa (d. 150/767) in some sources and did not find al-Zuhrī (d. 124/742), al-Qāsim b. 'Abdu'r-Rahmān (d. 116/734) and 'Abū Rūba in the list of his Shuyūkh. Consequently, he criticised his transmission of al-Hadìth al-Mutawātir al-lafzi from them. He questioned the authenticity of his chain of transmission that none of the biographical experts mentioned al-Zuhri among the Shuyūkh of Imām' Abu Hanifa as well as did not gave place to the biography of 'Abū Rūba in their lexicons. Similarly, al-Qāsim b. 'Abdu'r-Rahmān did not list in the chains via 'Abū Hanifa narrated from 'Abdullāh b. Masa'ūd. ${ }^{19}$

A thorough review of the mentioned conclusion revealed that Juynboll did not research the Shuyūkh of 'Abü Hanifa in all biographical lexicons. 'Abü Hanifa was the prominent student of 'Abū Rūba and $a l-Z u h r \bar{u}$, as Ibn Hibbān (d. 354/965), Ibn Kathīr (d. 774/1373) and al-Suyūtī (d. 911/1506) mentioned in their works. Moreover, al-Qāsim b. 'Abdu'r-Rahmān is one of his students as al-Mizzī (d. 742/1342) mentioned in Tahdhib al-Tahdhib and the transmission of 'Abu Hanifa from al-Qāsim b. 'Abdu'r-Rahmān is the narration of al-'Akābr from al'Asāghir.' ${ }^{20}$

\subsection{Vagueness in the Method of Selecting and Criticising of the Narrations:}

Undoubtedly, Juynboll provided scientific and detailed studies in supporting his claims. However, he selected some narrations and left others in one subject and did not make explicit his method in the weighting of narration that supports his 
theory over others. This ambiguity could be seen in his research about al- 'Awâil. He believes that the chain of transmission has been begun from al-Zuhrī. He supported his thesis on Mālik's narration from al- 'Awāil that recorded by $I b n^{\prime} A b \bar{\imath}$ Hātim (d. 327/939) "the first who used Isnād is Ibn Shihāb al-Zuhrī". ${ }^{21} \mathrm{He}$ ignored the same narration with another formulation: "the first who codified the knowledge -al-Hadìth-is Ibn Shihāb al-Zuhrī.". Both narrations belong to Mālik. However, he favoured the first over the second and did not explain its reason. ${ }^{22}$

\subsection{The Indulgence and the Violation of his Principles in Hukum on Isnād:}

He did not mention his method of Hukum on Isnād, but after extrapolation and following of his Hukum on different chains of hadith revealed his method that how he graded an Isnād as being Hijāzin, Irāqū, or Misrī. He looks at the Tabqa of al-Tabiün and their followers. If both narrators are from Irāq, he called the chain an Irāqi Sanad, and so on. However, he violated this approach in more than one place. Some of the chains were graded $\operatorname{Ira} q \bar{\imath}$ or $S h \bar{a} m \bar{\imath}$, despite there is one narrator from the mentioned region. ${ }^{23}$

\subsection{Manipulation in the Translation from Arabic into English:}

He quenched most of his studies from classical Arabic sources, indicating how fluent and expert he was in the Arabic language. Therefore, it might be an assumption that he erred in translating texts from Arabic into English because he was an expert of it. However, he translated it according to what pleases him and supports his theory. This manipulation has been noticed in his translation of narration from al-'Awāil regarding Egypt (أول من أظهر العلم في مصر). He translated the word al-'Ilam with tradition (al-Hadith) because he wants to support his theory of late transmission of hadith. ${ }^{24}$ Although the word al-'Ilam has a broad concept and the Muslim scholarship used it for Islamic Jurisprudence in the early ages of Islam, as al-Suyūtī did, it is compatible with Egypt's history. Yazid $b . A b \bar{\imath}$ Habib (d. 128) was not the first Muhaddith who introduced the transmission of hadith in Egypt. There were many Muhaddithün who entered Egypt, and the Egyptians transmitted from them before him, like the conquer of Egypt 'Amar $b$. al-'Aās, 'Abdullāh b. 'Amar b. al-'Aās, al-Zubair b. al-'Awām, 'Abdullāh b. Sa'ad, 'Abdullāh b. al-Hārith and others. Juynboll ignored these historical facts and translated the word al-'Ilam with tradition to prove his claim. ${ }^{25}$

\subsection{Neglection of Important Sources:}

It is revealed from a thorough follow-up of Juynboll sources that he benefited from some sources continuingly in every subject. However, he ignored them when he realised that the information in those sources goes against his theory. It is deduced from his dealings with al-Tabaqāt al-Kubrā, which is one of the most reliable sources in his studies. He referred to it in the criticism of the narrators and narrations on various subjects. However, he did not refer to him in the study of the first Muhaddith who entered Egypt because he claimed that Yazid b. Abi Habib was the first Muhaddith, who introduced the transmission of hadith to Egypt. while Ibn Sa'd listed him in the third Tabaqa of those Muhaddithūn who visited Egypt after the companions, and the Egyptians narrated 'Ahādith from them. Thus, he did not refer to al-Tabaqāt al-Kubrā in this subject. ${ }^{26}$ 


\subsection{Selective Methodology for Selective Conclusion:}

Juynboll developed the Common-link theory of Joseph Schacht. He explained it with a new approach and added other details. Both scholars tried to find out the dating of hadith through the Common-link in their studies. However, it is noticed that Juynboll ignored this method in the research about the dating of hadith alMutawātir and tried to study the mentioned hadith through "argumentum-esilentio" because he wants to conclude what support his theory. He dated the fabrication of al-Mutwātir al-Lafzī in Iraq between the death of al-Rabi $b . A b \bar{\imath}$ Habib (d. 175/792) and 'Abū Dāwūd al-Tiyālsī (d. 204/820). ${ }^{27}$ However, if he studied it through Common-link, 'Abu $D \bar{a} w \bar{u} d$ recorded it with different Isnads from Shu'ba Ibn al-Hajjāj (d. 160/777) who is the real Common-link of it that indicated that it was not fabricated in Iraq between (175-204) as Juynboll claimed. In fact, it was known to Muhaddithūn before the mentioned date in Iraq. However, he did not study it through Common-link even though his inference from argumentum-e-silentio is incorrect, but it supports his thesis. Therefore, he preferred it instead of Common-link. ${ }^{28}$

\section{Conclusion:}

The study reveals that Juynboll was the first orientalist of his family who specialised in Islam's primary sources. He focused on hadith studies and followed the methodology of Ignaz Goldziher and Joseph Schacht. He supported their thesis with significant evidence from the Classical Islamic Source and tried to introduce new methods for studying Prophetic hadith. Moreover, he studied Isnāds and Mutūn of Prophetic hadīths and concluded that 'Ahadìth are not a reliable source of Islamic law as Muslim scholarships believe. For example, he studied the al-Mutawātir al-Lafzī and al-Manawī and concluded that being a hadīth Mutawātir does not guarantee that it would not be fabricated. However, it proved that he did not refer to all sources of the mentioned hadiths.

It is concluded that Juynboll did not make his method explicit in the selection of narration. He preferred some narrations and ignored others while all related to the same subject as noticed in the study about the beginning of Isnād. Moreover, his methodology's follow-up reveals that he did not follow one method in the hadith study and violated his principles in different subjects.

It is noticed that he manipulated in the translation of some terms to support his thesis as he translated the word al-'Ilam in with tradition and concluded that Yazid $b$. 'Abi Habib was the first one who introduced the transmission of hadith in Egypt. However, it does not match with the historical facts because there were lots of Muhaddithūn before him, like the conquer of Egypt 'Amar b. al-'Ā̄s and his son 'Abdullāh, who was famous for the writing of 'Ahädith in the Prophet's life. It is also concluded that he usually refers to al-Tabaqāt al-Kubrā but neglected in this subject because Ibn Sa'ad mentioned Yazid b. 'Abi Habib in the third Tabaqa of those Muhaddithūn who entered Egypt.

Besides, he used a selective method for the desired conclusion as he developed the Common-link theory and used it for the dating of 'Ahädith in various subjects. Nevertheless, he did not investigate hadīth al-Mutawātir al-Lafzī through it and concluded that for the first time it appeared in Iraq between (175) and (204) A.H. 
However, it is revealed that Shu'ba b. al-Hajjāj (d. 160/777) was the Commonlink, which indicates that the mentioned hadith was famous among Muhaddithün before his claimed date.

\section{(C) (i) This work is licensed under a Creative Commons Attribution 4.0 International Licence.}

\section{References:}

1. Goldziher, Ignaz, Muslim Studies, Translated from the German by C. R. Barber And S. M. Stern (London, George Allen \& U N W I N Ltd, 1971), 2: 40-47.

2. Schacht, Josef, The Origins of Muhammadan Jurisprudence, (London: Oxford University Press, Ely House, 1950), 2-11.

3. Leon Buskens, "Collection Dr. Juynboll the Juynboll Family Library on Islamic and Arabic Studies", Burgersdijk \& Niermans, Nieuwsteeg I.2311 RW Leiden, the Netherland, 40.

4. Ibid, 40.

5/ Kizil, Fatma (2010). "Gualtherus (Gautier) Hendrik Albert Juynbol”, Hadis Tetkikleri Dergisi, 181.

6. Arie Schippers, Gauiter H.A Juynboll, https://vdocuments.site/gautier-h-ajuynboll.html, D.A. 10.11.2016.

7. Juynboll, G. H. A, My Days in Oriental Reading Room (Leiden: Ter Lugt Press, 2011), 5

8. Kizil, “Gualtherus...”, . 182. Juynboll, My Days in...,. 5, 14.

9. Juynboll, My Days in..., 5, 14.

10. https://www.library.universiteitleiden.nl/special-collections/research-in-specialcollections/juynboll-fellowship, D.A. 16.02.2017

11. Juynboll, G. H. A, Muslim Tradition, (Cambridge University Press, 1983), 1-76

12. Juynboll, Muslim tradition, 96-244.

13. "But once the mutabiat and the shawahid are recognized for what they are, he is left with the original bundle in its pristine form with a discernible CL who could be held responsible for the (wording of the) tradition scrutinized". Juynboll G.H.A (2007), Encyclopedia of Canonical Hadìth, Brill, Leadon. Boston, p. xxvi. Also see: pp. (xxvii, 37, 61, 66, 68, 77, 91, 118, 123, 164, 208, 221, 224, 225, 238, 309, $320,423,486,494,636,679,698,700,704,710,717,726)$.

14. 1.The Hadīth in the Discussion on Birth Control (Actas IV Congress de Estudos Arabes e Islamicos, Coimbra- Lisboa 1 a 8 de Stembro de 1968, ed. Antonio Dias Farinha, Leiden (1971), p. 373-379). 2. Ahmad Muhammad Shakir (1892-1958) and his Edition of Ibn Hanbal's Musnad (Der Islam, XLII (1972), p.221-247). 3.The Date of Great Fitna (Arabica, XX/2 (1973), s. 142-159).

Qurra in Early Islamic History (Journal of Economic and Social History of the Orient, XVI/2-3 (1973), p.113-129). 5.The Position of Quran Recitation in Early Islam (Journal of Semitic Studies, XIX/2 (1974), p. 240-252). 6. The Quran Reciter on the Battlefield and Concomitant Issues (Zeitschrift der Deutschen Morgenlandischen Gesellschaft, CLXXV (1975), p.11-27). 7. On the Origins of Arabic Prose (Studies on the first century of Islamic Society, ed. G.H.A Juynboll, Carbondale 1982, p. 161-175). 8. Dyeing the Hair and Beard in Early Islam: A Hadīth - Analytical Study (Arabica, XXXIII/1 (1986), s. 49-75). 9. Some New Ideas on the Development of Sunna as a Technical Term in Early Islam (Jerusalem 
Studies in Arabic and Islam, X (1987), p. 97-188). 10. Some Isnad Analytical Methods Illustrated on the basis of Several Woman-Demeaning Saying from Hadīth Literature (el- Qantara, X/2 (1989), p. 343-383). 11. The Role of Muammerun in the Early Development of the Isnad (Wiener Zeitschrift fur die Kunde des Morgenlandes, LXXXI (1991), p. 155-175). 12. Some Notes on Islam's First Fuqaha Distilled form Early Hadīth Literature (Arabica, XXXIX/3 (1992), p. 287-314). 13. Nafi, the Mawla of Ibn Umar, and his Position in Muslim Hadith Literature (Der Islam, LXX (1993), p. 207-244). 14. Early Islamic Society as Reflected in its Use of Isnads (Le Museon, CVII (1994), p. 151-199). 15. Shu'ba b. al-Hajjaj (d. 160/776) and his Position among the Traditionists of Basra (Le Museon, CXI (1998), p. 187-226). 16. (Re-) Appraisal of Some Technical Terms in Hadìth Science (Islamic law and Society, VIII/3 (2001), (303-349).

15. Juynboll, Muslim Tradition, 60, 69, 81, 82, 110, 127, 129, 163, 170, 199, 200, 206, 217. Encyclopedia of Canonical Hadìth, xxvi, xxvii, 37, 61, 66, 68, 77, 91, 118, 123, 164, 208, 221, 224, 225, 238, 309, 320, 423, 486, 494, 636, 679, 698, 700, 704, 710, 717, 726. Re)Appraisal of Some Technical Terms in Hadìt Science, 304348.

16. Juynboll, Muslim Tradition, 109, 110, 112, 113, 124, 129, 130.

17. Juynboll, Muslim Tradition, 142, 217,218, 137.

18. Juynboll, Encyclopedia of Canonical Hadìth, p. Xviii; Muslim Tradition, 99-102. "(Re)Appraisal of Some Technical Terms in Hadīth Science", 304-348. "The Date of Great Fitna", 142-159.

19. Juynboll, Muslim Tradition, 122-123.

20. Al-Mizzī, Yūsuf b. Abdu'r-Rahmān, Tahzib al-Kamāl, ed. Bshār Awād (Beirut: alRisāla, 1410/1980), 23: 449. Ibn Hibān, Muhammad b. Hibānn b. Ahmad, alThiqāt, (India: Dāiratu'l-Maārif al-Uthmānia, 1393/1973), 4: 357. Ibn Kathīr, Abū'l-Fidāa Ismāil b. Umar al-Dimashqī, al-Bidāya wa 'l-Nihāya, (Beirut: Dāru'lFikr, 1407/1987), 10: 107. al-Suyūtī, Tabaqāt al-Huffāz, (Beirut: Dāru'l-Kutub alIlmia, 1403/1983), 80.

21. Juynboll, Muslim Tradition, 18-19.

22. Ibn Asākr, Tārikh Dimashq, (Beirut: Dāru'l-Fikr, 1415/1995), 55: 334.

23. Juynboll, Muslim Tradition, 105-107. Ibn Abī Shiba, Musanaf, (al-Riyādh, Maktabatu'r-Rashid, 1409/1989), 3: 62. Ibn Saad, Abū Abdillāh Muhammad b. Saad al-Basrī, al-Tabaqāt al-Kubrāa, (al-Madina: Maktaba al-Ulūm, 1408/1988), 1, 3: 109-110, 156.

24. Juynboll, Muslim Tradition, 22-23.

25. Ibn Hajar, Tahzibu'l-Tahzib, (India: Dāiratu'l-Mārif, 1336/1918), 11: 319. alSuyūtī, al-Wasāil fi Musāmrati'l-Awāil, (Beirut: D āru'l-Kutub al-Ilmia, 1406/1986), 103. Ibn Saad, al-Tabaqāt al-Kubrā, 7: 342-356.

26. Juynboll, Muslim Tradition, 22. Ibn Sa'ad, al-Tabaqāt al-Kubrāa, 7: 342-356

27. Juynboll, Muslim Tradition, 124.

28. Motzki, Harld, (2005). "Dating Muslim Traditions a Survey”, Arabica, T. 52, Fasc. 2. (204-253). 